\title{
RATIONAL THERAPY OF URINARY TRACT INFECTIONS IN CHILDREN IN CROATIA
}

\author{
Danko Milošević, ${ }^{1,3}$, Danica Batinić ${ }^{2}$, Vladimir Trkulja ${ }^{1,3}$, Arjana Tambić Andraševićc ${ }^{4}$ \\ Borislav Filipović Grčić $c^{1}$, Kristina Vrljičak ${ }^{1}$, Boro Nogalo ${ }^{2}$, Daniel Turudićn ${ }^{3}$ and Marija Spajićs \\ ${ }^{1}$ Zagreb University Hospital Center, University of Zagreb School of Medicine; ${ }^{2}$ Srebrnjak Children's Hospital; \\ ${ }^{3}$ University of Zagreb School of Medicine; ${ }^{4} \mathrm{Dr}$. Fran Mihaljević University Hospital for Infectious Diseases, Zagreb; \\ ${ }^{5}$ Karlovac General Hospital, Karlovac, Croatia
}

\begin{abstract}
SUMMARY - Resistance to chemotherapeutics used in the treatment of urinary tract infection is increasing throughout the world. Taking into account clinical experiences, as well as current bacterial resistance in Croatia and neighboring countries, the selection of antibiotic should be the optimal one. Treatment of urinary tract infection in children is particularly demanding due to their age and inclination to severe systemic reaction and renal scarring. If parenteral antibiotics are administered initially, it should be switched to oral medication as soon as possible. Financial aspects of antimicrobial therapy are also very important with the main goal to seek the optimal cost/benefit ratio. Financial orientation must appreciate the basic primum non nocere as a conditio sine qua non postulate as well.
\end{abstract}

Key words: Child; Urinary tract infections - drug therapy; Antibacterial agents - therapy; Drug resistance, bacterial

\section{Introduction}

Microbial resistance to chemotherapeutics in therapy of common urinary tract infections (UTIs) is one of the major problems in pediatrics ${ }^{1}$. A rational UTI therapy taking into account local bacterial resistance is necessary to prevent or at least postpone further microbial resistance ${ }^{2,3}$. The existing therapeutic guidelines on managing UTI in Croatian children are nearly 10 years old ${ }^{4,5}$. We propose UTI antibiotic administration taking into account clinical experiences, current bacterial resistance and local directing regimen in Croatia and its neighboring countries (Bosnia and Herzegovina, Serbia and Slovenia) that are influencing microbial flora in Croatia and vice versa ${ }^{2,6-9}$. Our antibiotic proposals comprise financial aspects of therapy as well.

Correspondence to: Danko Milošević, $M D, P h D$, Zagreb University Hospital Center, University of Zagreb School of Medicine, Kišpatićeva 12, HR-10000 Zagreb, Croatia

E-mail: danko.milosevic@zg.t-com.hr

Received March 10, 2016, accepted April 21, 2016

\section{Resistance to Common Chemotherapeutics for Urinary Tract Infections}

Urinary tract infection is defined as inflammation caused by a pathogen and occurring anywhere along the urinary tract. The children with uncomplicated UTIs (without urinary tract anomalies) with unexpected bacterial resistance (UBR) are febrile/non febrile, have no severe systemic reaction and usually negative urinary tract ultrasound (US) examination ${ }^{10}$. The children with complicated UTIs (with urinary tract anomalies) are usually febrile above $38^{\circ} \mathrm{C}$, have loin pain/tenderness and body systemic reaction, as well as positive/negative US urinary tract examination. The latter group also includes children with previously recorded urinary bacterial resistance, recurrent UTIs (>3 UTIs) and proven cystitis cystica (endoscopically proven/US measurement $>3.9 \mathrm{~mm}$ bladder wall thickness $)^{11}$. Expected bacterial resistance (EBR) in this group is likely ${ }^{11,12}$.

If one does not take into account the current resistance of bacteria causing UTI, then the first choice of 
Table 1. Evaluation of suggested algorithm

COMMON (MOST PREVALENT) URINARY TRACT INFECTIONS IN CHILDREN

\section{WORKING DIAGNOSES}

- CYSTITIS

- CYSTOPYELONEPHRITIS

\section{LEVELS OF MEDICAL CARE}

- PRIMARY - primary/pediatric care

- SECONDARY - hospital/clinical care

- TERTIARY - pediatric nephrologists

\section{ELEMENTS}

- DIAGNOSTICS - recommended imaging vs not recommended (based on therapeutic decision making value and cost)

- THERAPY - recommended therapy options (based on efficacy and cost)

- MODALITIES OF HEALTH CARE - home, day-care hospital, hospitalization (based on efficacy and cost)

antimicrobial chemotherapeutic is often not the optimal one. This is the most common error in clinical practice. Second most common error is uncritical reliance on general advice about chemotherapeutic treatment of UTI based on experience in other countries, which can have a different microbial resistance pattern. The aforementioned two errors are serious because they can lead to inappropriate antibiotic prescription by local physicians. Lack of physician experience and inappropriate administration of antibiotics is also a possible source of errors. The result may be bacterial blood dispersal which hinders antibiotic bacterial control and/or increases the possibility of renal scarring ${ }^{5,13}$. Children at a high risk of serious illness and infants younger than 3 months should be referred to the care of pediatric specialist ${ }^{14}$ (Table 1 ).

\section{Financial Aspects of Antimicrobial Therapy}

Financial aspects of antimicrobial therapy are also very important despite the fact that in Croatia public insurance covers all approved therapeutic procedures. The basic financial rule of any antimicrobial therapy is that the most expensive therapy is an unsuccessful one. The patient's condition has not changed or it may even worsen and the resources allocated to unsuccessful treatment are wasted. When the initial antibiotic therapy turns out to be inappropriate, then more costly antibiotics which are normally kept as a reserve for prevention of more increasing bacterial resistance are hastily and sometimes improperly administered. The first 3 days are a critical period for therapy misjudgment. If the child with UTI does not demonstrate the expected clinical/urine response within 2 days of antimicrobial therapy, a change of antimicrobial should be considered. If the child does not receive proper therapy, the child's general condition deteriorates and prolonged hospitalization is required. In such condition, the child usually needs additional therapy support (fluid infusions, antipyretics, additional laboratory tests, repeated urine cultures, blood cultures, etc.). Antibiotic expenses during 2-4 days of therapy misjudgment must be added. Parenteral infusion supplies and its maintenance require additional medical care. Total cost of therapeutic misjudgment cannot be entirely predicted but it remarkably increases the cost/benefit ratio. Initial therapy misjudgment prolongs nursing/ food personnel expenses for an additional 3-4 days on average and their costs should be added to final therapy expenses. Parental discomfort for prolonged child's hospitalization after the initial unsuccessful antibiotic treatment is not a negligible factor either. Contrary, appropriate and timely antibiotic administration allows physician to switch to oral therapy after initial parenteral application for approximately 3-4 days, thus shortening hospital stay.

Positive outpatient clinical influence on treatment expenses is obvious. Total cost for each consecutive day in outpatient clinic is considerably lower (3.5 times). Transition to outpatient clinic is plausible after 24 hours of body temperature normalization. The cost/ benefit ratio after switch therapy is quite considerable. Prerequisite for switch therapy is clear: the change must not in any way influence the quality and outcome of the child's therapy. Additional favorable goal is achieved by home parental nursing and care, avoiding hospitalization trauma as much as possible.

Laboratory test expenses can also be considerable. The cost of medical supplies (syringes, needles, etc.) 
Table 2. Working diagnosis: cystitis (including urethrocystitis with hematuria) - all age groups

\section{PRIMARY OR SECONDARY HEALTH CARE}

\section{DIAGNOSTICS}<smiles>C1CCCCC1</smiles>

RECOMMENDED urine, urine culture

NOT

RECOMMENDED CRP, CBC

\section{ANTIMICROBIAL}

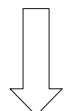

RECOMMENDED

Oral therapy, 7-10 day

duration

Empirical: nitrofurantoin, cefuroxime

Alternative: cefalexin, cefixime

NOT

\section{RECOMMENDED}

- as initial therapy:

ampicillin, sulfamethoxazole + trimethoprim

- cranberry products as stand-alone therapy or as switch/continuation medication
HEALTH CARE

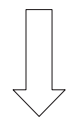

RECOMMENDED

Outpatient/home treatment
HIGHER HEALTH CARE

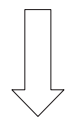

RECOMMENDED

Refer to a nephrologist after antibicrobial treatment for urinary tract ultrasound

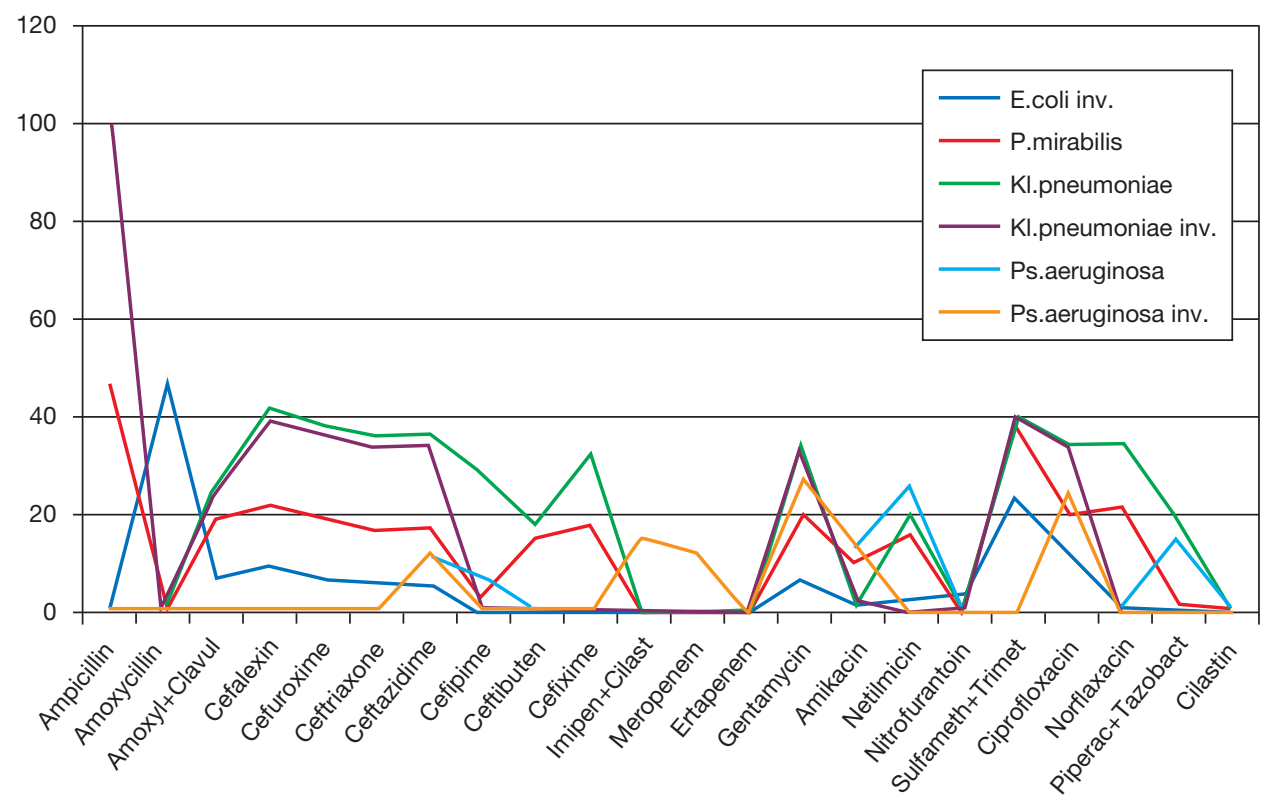

Fig. 1. Antibiotic resistance to Escherichia coli invasive strains, Proteus mirabilis, Klebsiella pneumoniae, Klebsiella pneumoniae invasive strains, Pseudomonas aeruginosa and Pseudomonas aeruginosa invasive strains. 
should also be added to the total cost. We recommend avoiding simultaneous $\mathrm{C}$-reactive protein $(\mathrm{CRP}) /$ erythrocyte sedimentation rate (ESR)/procalcitonin assessment, as it is unnecessary for diagnostic purpose. Blood culture should be reserved for urosepsis with the presumable bacterial resistance. Some laboratory data should be repeated on the third consecutive day (total white blood cell (WBC) count, $\mathrm{CRP} / \mathrm{ESR} /$ procalcitonin, urine sediment \pm leukocyte $/ \mathrm{mm}^{3}$ count, urine culture, rarely blood culture after previous positive sample). We strongly recommend clinical judgment and clinical purpose/cost evaluation. Expenses of cannula, syringes and infusion sets increase the total cost of parenteral therapy as well. For the majority of parenteral antibiotics, variable solutions as dilution medium are required for its administration. Therefore, their cost should be added to total antibiotic expenses. If such solutions are used several times a day for parenteral antibiotic administration, the possibility of media contamination increases. Xylocaine for intramuscular application is rarely required but also rarely added to the cost of antibiotics. Therefore, we recommend antibiotic/Xylocaine ready-made added preparations.

\section{Outpatient, General and Hospital Therapeutic Recommendations}

\section{Cystitis}

Oral therapy is recommended, only leukocyturia and/or hematuria require urine assessments and urine culture for diagnostic purpose. Therapy should be administered for 7-10 days. The cost/benefit ratio for urinary antiseptics (nitrofurantoin) is favorable, alternatively first or second generation cephalosporine or Amoxyl + clavulanic acid antimicrobials can be considered. Cephalosporin $3^{\text {rd }}$ generation antibacterial line antibiotics should be applied in case of presumed bacterial resistance. Cranberry preparations are not recommended as stand-alone therapy or as switch therapy extension, nor probiotics should be used for the same purpose ${ }^{15,16}$. The cost/benefit utility of such medication/UTI prophylaxis is dubious, considering its antibacterial effectiveness and parental financial burden ${ }^{17}$. Diagnostic procedures for cystitis require only kidney and urinary tract ultrasound (US) examination. Ampicillin and sulfamethoxazole-trimethoprim antimicrobials are not recommended as initial therapy (Table 2, Fig. 1).

\section{Cystopyelonephritis}

Parentera1/oral therapy is recommended depending on the child overall condition, urine (leukocyturia and/or hematuria) and urine culture are needed for diagnostic purposes, further diagnostic workup should be reserved for pediatrician/pediatric nephrology specialist judgment. Newborn and early neonatal UTIs should be considered primarily as systemic infections. In such patients and in children with septicemia switch to oral therapy must be carefully considered because oral medication intolerance is frequent ${ }^{5}$. Children below 2 years with toxic appearance, dehydration and inability to retain oral intake usually require hospital treatment ${ }^{13}$. Such children are also prone to renal scaring after UTIs ${ }^{18}$. Administration of antimicrobials in therapeutic or prophylactic dosages until the imaging studies are completed should be considered ${ }^{13}$. Oral therapy should be considered in children with good compliance and low systemic inflammatory parameters (axillary temperature up to $38.5^{\circ} \mathrm{C}$, CRP below 50 , leukocyte count below $\left.20 \times 10^{9} / \mathrm{L}\right)^{2}$. Oral vs. initial parenteral + switch to oral therapy should be carefully considered $^{13,15,19}$. Underestimation of the severity of UTI or/and hasty shortening of parenteral/oral therapy duration may lead to UTI recurrence and evolution to cystitis cystica ${ }^{12,20,21}$. In this case, the potentially long antibacterial chemoprophylaxis is often needed, with poor cost/benefit ratio ${ }^{12}$. Recommended therapy duration is $10-14$ days, rarely 7 days (gentamicin). Routine parenteral infusions are not necessary as they substantially increase expenses with questionable benefit. ESR can replace $\mathrm{CRP} /$ procalcitonin as the UTI severity marker, with favorable cost/benefit ratio. Serum creatinine level should be determined only in severe systemic infections (Table 3).

\section{Empirical UTI Antibiotic Recommendations}

Based on recently published articles and discussions with most pediatric nephrologists/infectologists and clinical microbiologists in Croatia, some basic preliminary general consensus about antibiotic administration can be achieved. Respecting current empirical UTI antibiotic prescriptions among pediatric nephrologists and using recent data on bacterial sensitivity/ resistance, we can provide some common remarks for antibiotic/urinary antiseptic use (Tables 1-4, Fig. 1). 
Table 3. Working diagnosis: cystopyelonephritis - all age groups

\begin{tabular}{l|l|l|}
\hline &
\end{tabular}

\section{Antibiotics/urinary antiseptics}

Ampicillin. At least $48 \%$ of common bacteria causing UTI (Escherichia (E.) coli, Proteus mirabilis) in our population are highly resistant to ampicillin (Fig. 4). Studies in Croatia, neighboring countries and world population show even higher percentage of bacterial resistance ${ }^{3,5,7,22-26}$. As the highest resistance is recorded in neonates, single ampicillin administration cannot be recommended ${ }^{27}$. In EBR children group with expected $100 \%$ bacterial resistance to ampicillin (Klebsiella pneumoniae, Pseudomonas aeruginosa) it should be entirely disregarded. Ampicillin for parenteral use has to be imported by emergency procedure, which increases its cost substantially, without adequate treatment benefits. Ampicillin has already been disregarded for primary UTI therapy/bacterial chemoprophylaxis in Croatia ${ }^{5,22}$. We now observe a higher bacterial sensitivity percentage than previously reported, which may reflect its partial sensitivity recovery. At present, antibacterial sensitivity for common bacteria causing UTIs is still low and its use as initial oral or parenteral antibacterial therapy of UTIs cannot be recommended. Its use as bacterial chemoprophylaxis is not justified either.

Amoxyl + clavulanic acid. We have observed a wide range of bacterial resistance in E. coli, Proteus mirabilis and Klebsiella pneumoniae; the lowest percentage showed E. coli strains (7\%) (Fig. 1). As E. coli strains are the most common cause of UTIs in UBR group of children, its oral use in uncomplicated UTIs is justified. Moderate resistance has been observed for Proteus mirabilis (19\%) and Klebsiella pneumoniae (26\%). Its cost for parenteral use (q6h frequency) is similar to 
Table 4. Antibiotics listed according to clinical side effects, expenses and empirical treatment recommendations

\begin{tabular}{|c|c|c|c|c|c|}
\hline & Resistance & $\begin{array}{l}\text { Clinically } \\
\text { related side } \\
\text { effects }\end{array}$ & Expenses & Other & $\begin{array}{l}\text { Empirical treatment } \\
\text { recommendations }\end{array}$ \\
\hline $\begin{array}{l}\text { Amoxicillin }+ \\
\text { clavulanic acid }\end{array}$ & $\begin{array}{l}\text { Depending } \\
\text { on bacterial } \\
\text { causes: low to } \\
\text { moderate. }\end{array}$ & $\begin{array}{l}\text { Gastric } \\
\text { disturbances }\end{array}$ & $\begin{array}{l}\text { Single: favorable. } \\
\text { Total: favorable }\end{array}$ & $\begin{array}{l}\text { Oral intake. } \\
\text { Suitable for } \\
\text { outpatient } \\
\text { clinic }\end{array}$ & $\begin{array}{l}\text { RECOMMENDATION } \\
\text { for sensitive E. coli strains). } \\
\text { Possible short UTI } \\
\text { prophylaxis }\end{array}$ \\
\hline $\begin{array}{l}\text { Ampicilin + } \\
\text { gentamicin }\end{array}$ & $\begin{array}{l}\text { Ampicillin } \\
\text { - high } \\
\text { (all strains). } \\
\text { Ampicillin } \\
\text { increases } \\
\text { amoxicillin } \\
\text { resistance }\end{array}$ & $\begin{array}{l}\text { Irreversible } \\
\text { ototoxicity } \\
\text { and } \\
\text { vestibulotoxicity } \\
\text { of gentamicin } \\
\text { - especially } \\
\text { at maximum } \\
\text { dosage } 5 \mathrm{mg} / \mathrm{kg} \\
\text { Nephrotoxicity } \\
\text { Neurotoxicity }\end{array}$ & $\begin{array}{l}\text { Single: } \\
\text { unfavorable } \\
\text { (ampicillin } \\
\text { emergency } \\
\text { imports) } \\
\text { Total: potentially } \\
\text { high due to side } \\
\text { effects and } \\
\text { recommended } \\
\text { 3rd day serum } \\
\text { gentamicin } \\
\text { concetration } \\
\text { determination }\end{array}$ & $\begin{array}{l}\text { Unfavorable } \\
\text { for outpatient } \\
\text { clinic } \\
\text { (multiple daily } \\
\text { dosage) }\end{array}$ & $\begin{array}{l}\text { NOT RECOMMENDED } \\
\text { for empirical treatment } \\
\text { (except for neonatal sepsis } \\
\text { treatment) }\end{array}$ \\
\hline Gentamicin & $\begin{array}{l}\text { Depending } \\
\text { on bacterial } \\
\text { causes: } \\
\text { low to high }\end{array}$ & As above & $\begin{array}{l}\text { Single: favorable. } \\
\text { Total: as above }\end{array}$ & $\begin{array}{l}\text { Favorable } \\
\text { for outpatient } \\
\text { clinic (dosage } \\
\mathrm{q} 24 \mathrm{~h} \mathrm{r} / 12 \mathrm{~h} \text { ) }\end{array}$ & $\begin{array}{l}\text { RECOMMENDATION } \\
\text { (for sensitive strains - up to } \\
7 \text { day treatment). }\end{array}$ \\
\hline Cefuroxime & $\begin{array}{l}\text { E. coli- low. } \\
\text { Other bacteria } \\
\text { moderate, } \\
\text { K. pneumoniae } \\
\text { - high. }\end{array}$ & Rare & $\begin{array}{l}\text { Single: favorable. } \\
\text { Total: favorable }\end{array}$ & $\begin{array}{l}\text { Parenteral } \\
\text { treatment } \\
\text { unfavorable } \\
\text { for outpatient } \\
\text { clinic (tid). } \\
\text { Switch to oral } \\
\text { therapy } \\
\text { favorable }\end{array}$ & $\begin{array}{l}\text { RECOMMENDATION: } \\
\text { first choice for a particular } \\
\text { diesase severity and child's } \\
\text { age. Possible switch to oral } \\
\text { therapy } \\
\text { (Cefixime Ceftibuten) }\end{array}$ \\
\hline Ceftriaxone & $\begin{array}{l}\text { E. coli-low, } \\
\text { K. pneumoniae } \\
\text { - moderate }\end{array}$ & Rare & $\begin{array}{l}\text { Single: favorable } \\
\text { Total: favorable } \\
\text { (especially with } \\
\text { already added } \\
\text { solution } \\
\text { for dilution } \\
\text { in package) }\end{array}$ & $\begin{array}{l}\text { Favorable } \\
\text { for outpatient } \\
\text { clinic }(q d)\end{array}$ & $\begin{array}{l}\text { RECOMMENDATION: } \\
\text { first choice treatment. } \\
\text { Especially suitable for oral } \\
\text { switch therapy }\end{array}$ \\
\hline Meropenem & $\begin{array}{l}\text { Low - all } \\
\text { strains }\end{array}$ & Rare & $\begin{array}{l}\text { Single: high } \\
\text { Total: high }\end{array}$ & $\begin{array}{l}\text { Unfavorable } \\
\text { for outpatient } \\
\text { clinic (tid) }\end{array}$ & $\begin{array}{l}\text { RECOMMENDATION: } \\
\text { favorable second choice } \\
\text { for neonatal therapy }(\leq 1 \mathrm{mo}) \\
\text { and sepsis Change to other } \\
\text { parenteral therapy ASAP } \\
\text { after L.P. }\end{array}$ \\
\hline
\end{tabular}


Table 4. Continued

\begin{tabular}{|c|c|c|c|c|}
\hline $\begin{array}{l}\text { Sulfametho- } \\
\text { xazole }+ \\
\text { Trimethoprim }\end{array}$ & $\begin{array}{l}\text { Depending } \\
\text { on strains: } \\
\text { moderate } \\
\text { to high. }\end{array}$ & & $\begin{array}{l}\text { Single: favorable. } \\
\text { Total: potentially high } \\
\text { due to failure }\end{array}$ & $\begin{array}{l}\text { RECOMMENDATION: } \\
\text { Not recommended as first } \\
\text { choice therapy. Suitable } \\
\text { for outpatient clinic for } \\
\text { sensitive strains. Not suitable } \\
\text { for UTI prophylaxis }\end{array}$ \\
\hline $\begin{array}{l}\text { Nitro- } \\
\text { furantoin }\end{array}$ & $\begin{array}{l}\text { Low - } \\
\text { common } \\
\text { strains }\end{array}$ & $\begin{array}{l}\text { Gastric } \\
\text { disturbances, } \\
\text { Infants: } \\
\text { vomiting } \\
\text { (compliance) }\end{array}$ & $\begin{array}{l}\text { Single: favorable } \\
\text { Total: best cost/benefit ratio }\end{array}$ & $\begin{array}{l}\text { RECOMMENDATION: } \\
\text { Favorable for outpatient } \\
\text { clinic and switch therapy. } \\
\text { First choce for UTI } \\
\text { prophylaxis }\end{array}$ \\
\hline Cephalexin & $\begin{array}{l}\text { Depending on } \\
\text { strains: low to } \\
\text { moderate. }\end{array}$ & & $\begin{array}{l}\text { Single: favorable } \\
\text { Total: favorable }\end{array}$ & $\begin{array}{l}\text { RECOMMENDATION: } \\
\text { As above. Good choice } \\
\text { for oral switch therapry } \\
\text { and UTI prophylaxis }\end{array}$ \\
\hline Cefixime & As above. & & $\begin{array}{l}\text { Single: favorable. } \\
\text { Total: favorable }\end{array}$ & $\begin{array}{l}\text { RECOMMENDATION: } \\
\text { As above. Good choice } \\
\text { for oral switch therapy } \\
\text { and UTI prophylaxis } \\
\text { (especially with } \\
\text { nitrofurantioin intolerance) }\end{array}$ \\
\hline $\begin{array}{l}\text { Cipro- } \\
\text { floxacin/ } \\
\text { norfloxacin }\end{array}$ & As above & $\begin{array}{l}\text { Gastric } \\
\text { disturbances, } \\
\text { seizures }\end{array}$ & $\begin{array}{l}\text { Single: favorable } \\
\text { Total: favorable }\end{array}$ & $\begin{array}{l}\text { RECOMMENDATION: } \\
\text { Good choice for sensitive } \\
\text { strains }\end{array}$ \\
\hline $\begin{array}{l}\text { Piperacillin } \\
+ \text { tazobactam, } \\
\text { cefipime, } \\
\text { ertapenem, } \\
\text { colistin }\end{array}$ & $\begin{array}{l}\text { Low } \\
(P s . \\
\text { aeruginosa) }\end{array}$ & & $\begin{array}{l}\text { Single: high } \\
\text { Total: high }\end{array}$ & $\begin{array}{l}\text { RECOMMENDATION: } \\
\text { exclusively for sensitive } \\
\text { strains }\end{array}$ \\
\hline
\end{tabular}

ampicillin. The recently reduced use of amoxicillin + clavulanic acid as the choice of treatment for upper respiratory tract/UTIs decreased its resistance rate ${ }^{3,22}$. Following its anew widespread use, we should expect its sensitivity decrease in the future. In EBR group with previously isolated Pseudomonas aeruginosa, its use must be entirely disregarded. To prevent further bacterial resistance, its administration for UTI chemoprophylaxis should be avoided.

Sulfamethoxazole + trimethoprim. We found a wide range of bacterial resistance (E. coli, 24\%; Proteus mirabilis, 19\%; and Klebsiella pneumoniae, 41\%) to all examined agents, which was somewhat expected ${ }^{3,5,22}$. The most likely explanation for this low bacterial sensitivity is its widespread use for UTI chemoprophylaxis in Croatia. Similar observations were noticed in the neighboring countries ${ }^{6,7,23,24}$. Its oral administration in UBR group cannot be labeled as a first-line antibiotic choice as its resistance rate makes this drug less suitable for empirical treatment ${ }^{25,28}$. It should be particularly avoided in EBR patients with expected Pseudomonas aeruginosa strains. Therefore, chemoprophylactic use of sulfamethoxazole + trimethoprim is also highly questionable and should be avoided in children with urinary tract abnormalities ${ }^{22}$. If restricted as chemoprophylactic agent, this drug could regain part of its former bacterial sensitivity. Antibacterial activity is not increased by adding sulfamethoxazole in UTI therapy caused by E. coli and the aforementioned combination has no advantage to sole trimethoprim ${ }^{29}$.

Nitrofurantoin. Despite its widespread use as a UTI chemoprophylactic agent, the resistance percent-

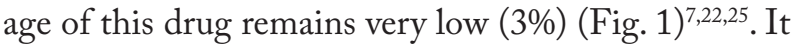
therefore makes the cost/benefit ratio of this drug very acceptable as primary oral therapy/chemoprophylactic medication for UBR group. Its high sensitivity in 
common bacterial flora causing UTIs in children in Croatia is probably due to its infrequent use in acute UTI UBR treatment ${ }^{22}$. Its main weakness is sometimes difficult oral tolerance and thus related poor compliance. Therefore, its administration in infancy is questionable. Nitrofurantoin is very convenient as oral switch therapy. We expect its more frequent use in the future and therefore close monitoring of its sensitivity/ resistance ratio is needed ${ }^{3}$. This drug is of limited use in EBR group because of the possible bacterial resistance. As urinary antiseptic medication, nitrofurantoin is not suited for parenteral treatment.

Cephalexin. We observed low antibacterial resistance of most common bacteria causing UTIs, with the lowest percentage in E. coli (9\%) (Fig. 1). Moderate resistance of Proteus mirabilis (22\%) and Klebsiella pneumoniae (39\%-41\%) was observed. Its recommendation as the first line UBR antibiotic treatment is similar to the Amoxyl + clavulanic acid and its use is supported by some local and neighborhood low bacterial resistance rates ${ }^{3,23}$. Its widespread use in UTI and bacterial respiratory diseases will probably lead to the rise of bacterial resistance, as already shown in neighboring countries ${ }^{23,30}$. Its use in EBR group of patients should be avoided if Pseudomonas aeruginosa is expected. Its cost for parenteral use is the same as for ampicillin. To prevent further bacterial resistance its chemoprophylactic use should be avoided.

Cefuroxime. E. coli showed low resistance (8\%) to this drug (Fig. 1). Cefuroxime and cephalexin share a similar resistance percentage in Proteus mirabilis (20\%) and Klebsiella pneumoniaae (37\%-39\%), which makes cefuroxime useful in the common UBR group of patients for oral and parenteral therapy. Because of its administration ( $\mathrm{q} 8 \mathrm{~h}$ frequency), its parenteral cost is somewhat lower than that of ampicillin. Such administration limits its outpatient clinic use due to parental discomfort. Maximal dosage $(100 \mathrm{mg} / \mathrm{kg}$ ) of this drug does not increase its antibacterial efficiency and does not contribute to reduction of the cost/benefit ratio. Switch from parenteral to oral therapy with cefuroxime is encouraged as soon as the child's health condition allows it, and bacterial sensitivity/resistance by urine culture is known. Its use in EBR group of patients should be avoided if Pseudomonas aeruginosa is expected. To prevent further bacterial resistance, its chemoprophylactic use should be avoided.
Cefixime. Due to low E. coli (6\%), Proteus mirabilis (18\%) and moderate Klebsiella pneumoniae (32\%) resistance percentage and only single dose/day administration, cefixime is quite suitable for UBR treatment and in particular for oral switch therapy and antimicrobial chemoprophylaxis ${ }^{5}$. Despite its use as a chemoprophylactic agent, we have not observed increase in its bacterial resistance.

Ceftriaxone. Low resistance of $E$. coli (6\%), low/ moderate Proteus mirabilis (17\%) and Klebsiella pneumoniae (34\%-36\%) resistance was observed (Fig. 1). It makes ceftriaxone very suitable for the UBR group of patients. It has already been recommended by previous studies in Croatia and neighboring countries, as well as by NICE recommendations as first line parenteral therapy ${ }^{2-5,7,10,14,22,23,25,31}$. We also agree with these conclusions. The recommended upper limit dosage of this drug is not justified as the supposed increase of UTI antibacterial efficiency has not been demonstrated. Even more, such administration significantly reduces the cost/benefit ratio and may even result in gallbladder/urinary ceftriaxone generated stones ${ }^{32,33}$. Fixed cost of its parenteral use is very favorable due to its once daily (24-h frequency) administration, especially if the solution for dilution of this drug has already been added. Its daily parenteral administration (intravenous/intramuscular) makes it very suitable for prolonged application in outpatient clinic with favorable parental comfort. As part of the cephalosporin antibiotic group, ceftriaxone is suitable for oral switch therapy with other cephalosporins (not exclusively). The only limitation of its use in EBR patient group is if Pseudomonas aeruginosa strains can be expected. Its exclusive parenteral use makes it completely inappropriate for chemoprophylactic purpose. With this limitation and restricted use for common bacterial respiratory disease treatment in Croatia, ceftriaxone contact with broad range bacterial flora is relatively limited. Close monitoring of its sensitivity/resistance bacterial pattern is necessary ${ }^{6}$.

Ceftazidime. We observed similar resistance of $E$. coli (5\%), Proteus mirabilis (17\%) and Klebsiella pneumoniae (34\%-36\%) as with previously mentioned ceftriaxone. Low Pseudomonas aeruginosa resistance (12\%) makes it suitable for the treatment of infections caused by these bacteria, if such strains are expected. Its use in UTIs and respiratory bacterial diseases is restricted in outpatient clinic by recommendations from physi- 
cians/pediatricians in Croatia, and reserved only for hospital treatment. We believe that it should be kept in reserve and used only for previously proven Pseudomonas strains or in life threatening infections with suspected antibacterial resistance. Its parenteral $\mathrm{q} 8 \mathrm{~h}$ administration makes it unsuitable for outpatient clinic administration. We do not recommend switch to oral therapy in Pseudomonas aeruginosa proven strains. Parenteral administration for 10-14 days is recommended.

Gentamicin. We observed low bacterial resistance of E. coli (6\%); moderate Proteus mirabilis (21\%) and Klebsiella pneumoniae (34\%) resistance was similar to ceftriaxone with $28 \%$ resistance of Pseudomonas aeruginosa strains. It is therefore suitable for the common UBR group of patients ${ }^{24}$. Due to its infrequent use in Croatia during the past decades, its sensitivity percentage seems to have improved, so this drug might at least partly regain its antibacterial activity ${ }^{3,5,31}$. The increasing resistance in neighboring countries and in the world warrants caution and close resistance monitoring $^{6,7,24,25,34,35}$. Its twice a day administration (q12h frequency) makes it useful in outpatient clinic application. Successful treatment is expected after 7 days of administration. Antibacterial activity of gentamicin has not improved significantly by adding ampicillin to the therapeutic schedule, but has considerably increased the fixed UTI parenteral treatment cost. As ampicillin in Croatia is obtained only through emergency import, the increase in its cost per amount is not justified. Such a combination of drugs increases resistance to ampicillin. It is only recommended in neonatal use where unknown and probably mixed gram positive/gram negative bacterial strains are expected ${ }^{2,31}$. Progressive increase of multidrug resistance was recently observed in newborns from the neighboring countries $^{27}$. Therefore, close monitoring of antimicrobial resistance to cephalosporins and aminoglycosides in this particular subgroup of children should be implemented $^{3,27}$. Additional problem of this drug is possible nephrotoxicity, as well as irreversible cochlear damage (3\%-14\%) and vestibulotoxicity (4\%-6\%) ${ }^{36}$. It is also excreted by breast milk ${ }^{36}$. Single daily parenteral administration does not reduce its oto/vestibulotoxic$i^{3}{ }^{36}$. A switch to oral therapy can reduce this risk. We do not recommend daily dosage of/above $5 \mathrm{mg} / \mathrm{kg}$ as such increase does not yield additional antibacterial efficiency. If administered in such upper limits of dosage, it is recommended to perform assessment of gentamicin serum concentration on the third day of administration. This assessment will certainly disrupt its cost/ benefit ratio. In selected cases, audiogram/vestibulogram is also indicated, which also influences its cost/ benefit ratio. In certain EBR children with Pseudomonas aeruginosa proven UTI infections, we observed discrepancy in in vitro/in vivo activity of this drug. Therefore, initial therapy with gentamicin after several days has to be replaced with another Pseudomonas aeruginosa therapy if laboratory urine/urine culture does not improve or becomes sterile. This failure of antibiotic treatment should also be perceived as contributing to unfavorable cost/benefit ratio. A strict policy of urine/urine culture check after third day of its administration is strongly recommended.

Amikacin. Low resistance of E. coli (1\%), Proteus mirabilis (10\%), Klebsiella pneumoniae (2\%) and Pseudomonas aeruginosa (13\%) makes amikacin suitable for antibacterial treatment instead of other aminoglycoside antibiotics (gentamicin) in the UBR/EBR group. However, its nephro/oto/vestibulotoxicity is comparable to gentamicin. Its parenteral administration (q8$12 \mathrm{~h}$ frequency) makes it unsuitable for outpatient clinic. Its cost is, however, similar to gentamicin. If administered, all recommendations regarding gentamicin also stand for this drug.

Meropenem/imipenem + cilastatin: E. coli, Proteus mirabilis, Klebsiella pneumoniae show no (0\%), and Pseudomonas aeruginosa (12\%) low resistance to this drug, making it the best choice for antibacterial UBR/EBR group of patients. To maintain none/low resistance rates, its administration must be kept as strict reserve. This drug should also be reserved for neonatal/early infant sepsis and for proven antibiotic resistance to the aforementioned antibiotic groups, especially if lumbar puncture was not performed or failed to achieve unmistakable result. Its daily administration (q8h frequency) makes this drug inappropriate for use in outpatient clinic. Its outpatient use is also restricted due to its administration in neonatal/low age children, severe illness related risk and parental discomfort. If possible, oral switch therapy is recommended in older children in order to maintain its antibacterial sensitivity.

Other antibiotics. Ceftibuten sensitivity percentages of E. coli (96\%), Proteus mirabilis (85\%) and Klebsiella pneumoniae (82\%) strains make it suitable for treatment of infections caused by these bacteria ${ }^{5}$. Low 
resistance rates of Proteus mirabilis (2\%), Klebsiella pneumoniae (19\%) and Pseudomonas aeruginosa (15\%) to piperacillin + tazobactam make this combination suitable for antibacterial treatment in urine culture selected $\operatorname{cases}^{37}$. Considerable piperacillin resistance was found in one of the neighboring countries, indicating the possibility of increasing resistance unless its use is put under strict control ${ }^{38}$. E. coli (4\%) and Proteus mirabilis (7\%) show low resistance and Klebsiella pneumoniae (28\%) moderate resistance to cefepime. It should be reserved primarily for Pseudomonas aeruginosa (7\% resistance) urine culture proven strains to avoid increase of resistance to this drug. According to Proteus mirabilis (16\%), Klebsiella pneumoniae (19\%) and Pseudomonas aeruginosa (26\%) resistance to netilmicin, this drug has similar antibacterial spectrum to that of gentamicin, with the same nephro/oto/vestibulotoxicity disadvantages. Ciprofloxacin/norfloxacin with E. coli (13\%), Proteus mirabilis (20\%), Klebsiella pneumoniae (34\%) and Pseudomonas aeruginosa (24\%) resistance rate make a promising choice for oral treatment of UBR. This treatment is still uncommon among pediatricians in Croatia. We should closely monitor its resistance rate as quinolones showed alarmingly significant increase in resistance rate in one of our neighboring countries ${ }^{7}$. Ertapenem (E. coli and P. mirabilis 0\%, Kl. pneumoniae 2\% resistance) should be kept in reserve and used after urine culture sensitive strains have been isolated. Considerable parental comfort is achieved by its administration. Colistin has Pseudomonas aeruginosa 0\% resistance, but due to its considerable nephrotoxicity it is only used after proven resistance to all the aforementioned antibiotics.

Advantages of effectiveness, safety and positive effect on UTI bacterial resistance in weekly single-dose versus continuous low-dose antibiotic prophylaxis on recurrent UTIs should be investigated.

\section{Empirical Estimation of Optimal Cost/Benefit Ratio}

Estimation of optimal cost/benefit ratio should take into consideration the existing empirical UTI antimicrobial prescription. Recent preliminary interviews with pediatric nephrologists and infectologists in Croatia were conducted in order to achieve the best possible solutions respecting previously published data ${ }^{4,5,22}$.These solutions are summarized and presented in this article after Annual Meeting of Pediatric Nephrologists in Rijeka 2014. We also assessed preliminary cost/benefit estimation from our experience. The best cost/benefit empirical therapy in children is still ceftriaxone/cefuroxime for parenteral therapy ${ }^{2,4,8}$. Ceftriaxone treatment is preferred in clinically and laboratory proven septicemia, especially if anomaly of urinary tract is expected. Switch to oral cephalosporin/ nitrofurantoin is encouraged as soon as possible $2,5,13$. This switch usually follows after clinical improvement and body temperature normalization for at least $24 \mathrm{~h}$. Before the ongoing studies on gentamicin nephro/cochlear/vestibulotoxicity are completed, we must consider this drug as the second best choice for UTI parenteral antimicrobial therapy ${ }^{2,4,8}$. The worst preliminary cost/benefit ratio for UTI treatment is associated with ampicillin + gentamicin combination. The best choice for oral therapy are cephalosporin/ amoxicillin + clavulanic acid groups of antibiotics. Nitrofurantoin medication should be encouraged after infancy. Full oral therapy in febrile children after infancy and in good physical condition is possible. The choice of sulfamethoxazole + trimethoprim for antibacterial chemoprophylaxis is indeed highly questionable and not preferred, but if ordered, trimethoprim alone is quite sufficient for this purpose ${ }^{29}$. Nitrofurantoin/cefixime is currently the best choice for antibacterial chemoprophylaxis. Bacterial resistance to all antibiotics should be monitored, assessed and updated in the form of annual report.

We therefore recommend foundation of children care clinical expert task force in all regions of Croatia with various specialists including pediatric nephrologists, pediatric infectologists, neonatologists, microbiologists, pharmacologists and outpatient clinical experts for monitoring bacterial resistance and implementation of the conclusions. Such national survey groups already exist in many countries with periodical reports published. Similar studies in other countries may uncover the real picture of antimicrobial resistance in general. A prospective clinical study is proposed. Therefore, coordination of primary, secondary and tertiary childhood care with diagnostic checklist and prescription of antimicrobials is essential ${ }^{1}$ (Table 1). Its purpose is to get current insight into bacterial sensitivity to antimicrobials and establishment of rational therapy checklist respecting cost/benefit ratios 
with ultimate goal of slowing down antimicrobial resistance. Our study must be compliant with similar studies in European and other countries. However, financial orientation does not mean that full awareness of primum non nocere as a conditio sine qua non postulate should be disrupted.

We recommend using antibacterial UTI prophylaxis in pharmacologically specified form and discourage the custom of breaking tablets or capsules in order to achieve a lower dose of antimicrobials.

This concept was approved by the assembly of the Croatian pediatric nephrologists in Rijeka.

\section{References}

1. Harmsen M, Adang EMM, Walters RJ, Van der Wouden JC, Gral RPTM, Wensing M. Management of childhood urinary tract infections: an economic modelling study. International Society for Pharmacoeconomics and Outcomes Research (ISPOR). 2009;12(4):466-71.

2. Zulić S, Tvica J. Infekcija urinarnog trakta u djece. Pedijatrija danas. 2007;3(2):164-76. (in Croatian)

3. Prohaska-Potočnik C, Vukadinović MV, Car H. Učestalost nalaza najčešćih bakterijskih uzročnika infekcije mokraćnog sustava i djece i njihova osjetljivost na antimikrobne lijekove. Med Jad. 2008;38(1-2):5-11. (in Croatian)

4. Šubat-Dežulović M. Urinarna infekcija u djece: postupnik za dijagnozu, liječenje i slikovnu obradu. Medix. 2005;600/601: 157-61. (in Croatian)

5. Tešović G, Batinić D. Infekcije mokraćnog sustava u djece. Medicus. 2006;15(2):275-82. (in Croatian)

6. Peco-Antic A, Paripovic D, Spasojevic-Dimitrijeva B, Buljagic S. Trend of antibiotic resistance in children with first acute pyelonephritis. Indian Pediatr. 2011;48:812-3.

7. Uzunovic-Kamberovic S. Antibiotic resistance of coliform organisms from community-acquired urinary tract infections in Zenica-Doboj Canton, Bosnia and Herzegowina.J Antimicrob Chemoter. 2006;58(2):344-8. doi: 10.1093/jac/dk1243

8. Kenda R. Liječenje infekcija mokraćnog sistema - novosti i stari problemi. Pediatr Croat. 2002;46 (Suppl 1):87-94. (in Croatian)

9. Ilić K, Jakovljević E, Skodrić-Trifunović V. Social-economic factors and irrational antibiotic use as reasons for antibiotic resistance of bacteria causing common childhood infections in primary healthcare. Eur J Pediatr. 2012;17(5):767-77. doi: 10.1007/s00431-011-1592-5

10. Batinić D. Bolesti mokraćnih i spolnih organa. In: Mardešić D, et al., Editors. Pedijatrija. Školska knjiga, Zagreb; 2000: p. 901-57. (in Croatian)

11. Milošević $\mathrm{D}$, Trkulja $\mathrm{V}$, Turudić $\mathrm{D}$, Batinić $\mathrm{D}$, Spajić $\mathrm{B}$, Tešović G. Ultrasound bladder wall thickness measurement in diagno- sis of recurrent urinary tract infections and cystitis cystic in prepubertal girls. J Pediatr Urol. 2013;9(6 Pt B):1170-7. doi: 10.1016/j.jpurol.2013.04.019

12. Milošević D, Batinić $D$, Tešović $G$, Konjevoda $P$, Kniewald $H$, Šubat-Dežulović M, Grković L, Topalović-Grković M, Turudić D, Spajić B. Cystitis cystica and recurrent urinary tract infections in children. Coll Antropol. 2010;34(3):893-7.

13. American Academy of Pediatrics. Urinary tract infection: clinical practice guideline for the diagnosis and management of the initial UTI in febrile infants and children 2 to 24 months. Pediatrics. 2011;128(3):595-610. doi:10.1542/peds.2011-1330

14. NICE guidelines. Urinary tract infection in under 16s: diagnosis and management. nice.org.uk/guidance/cg54 2007.

15. Alper BS, Curry SH. Urinary tract infection in children. Am Fam Physician. 2005;72(12):2483-8.

16. Schwenger EM, Tejani AM, Loewen PS. Probiotics for preventing urinary tract infections in adults and children. Cochrane Database Syst Rev. 2015 Dec 23;12:CD008772. doi: 10.1002/14651858.CD008772.pub2

17. Bosmans JE, Beerepoot MAJ, Prins JM, ter Riet G, Geerlings SE. Cost-effectiveness of cranberries vs antibiotics to prevent urinary tract infections in premenopausal women: a randomized clinical trial. PloS One. 2014; doi: 10.1371/journal.pone. 0091939,

18. Lin KY, Chiu NT, Chen MJ, Lai CH, Huang JJ, Wang YT, et al. Acute pyelonephritis and sequelae of renal scar in pediatric first febrile urinary tract infection. Pediatr Nephrol. 2003; 18:362-5. doi: 10.1007/s00467-003-1109-1

19. Roberts KB. Revised AAP guideline on UTI in febrile infants and young children. Am Fam Physician. 2012;86(10)940-6.

20. Vrljičak K, Milošević D, Batinić D, Kniewald H, Nižić L. The significance of ultrasonography in diagnosing and follow-up of cystic cystitis in children. Coll Antropol. 2006;30(2):355-9.

21. Vrljičak K, Turudic D, Bambir I, Gradiški IP, Spajić B, Batinić D, Topalović-Grković M, Spajić M, Batinić D, Milošević D. Positive feedback loop for cystitis cystica: the effect of recurrent urinary tract infection on the number of bladder wall mucosa nodules. Acta Clin Croat. 2013;52(4):444-7.

22. Ilić T, Gračan S, Arapović A, Capkun V, Subat-Dežulović M, Saraga M. Changes in bacterial resistance patterns in children with urinary tract infections on antimicrobial prophylaxis at University Hospital in Split. Med Sci Monit. 2011 Jul;17 (7):CR355-6. doi: 10.12659/MSM.881845

23. Stojanović V, Milošević B. Resistance of Escherichia coli, the most frequent cause of urinary tract infection in children, to antibiotics. Med Pregl. 2010;63(1-2):109-12.

24. Lazarević G, Petreska D, Pavlović S. Antibiotic sensitivity of bacteria isolated from the urine of children with urinary tract infections from 1986 to 1995. Srp Ann Celok Lek. 1998;126 (11-12):423-9.

25. Yuksel S, Ozturk B, Kavaz A, Ozcakar ZB, Acar B, Guriz H, Avsev D, Ekim M, Yalcinkaya F. Antibiotic resistance of urinary tract pathogens and evaluation of empirical treatment in Turkish 
children with urinary tract infections. Int J Antimicrob Agents. 2006;28(5):413-6. doi: 10.1016/j.ijantimicag.2006.08.009

26. Prelog M, Schiefecker D, Fille M, Wurzner R, Brumner A, Zimmerhackl LB. Febrile urinary tract infection in children: ampicillin and trimethoprim insufficient empirical mono-therapy. Pediatr Nephrol. 2008;23(4):597-602. doi: 10.1007/ s00467-007-0701-1

27. Peco-Antić A, Paripović D, Buljugić S, Kruščić D, Spasojević M, Cvetković M, Kostić M, Laban-Nestorović S, Miloševski-Lomić G. Antibiotic resistance of uropathogens in newborns and young children with acute pyelonephritis. Srp An Celok Lek. 2012;140(3-4):179-83.

28. Swerkersson S, Jodal UJ, Ahren C, Hansson S. Urinary tract infection in small outpatient children: the influence of age and gender on resistance to oral antimicrobials. Eur J Pediatr. 2014;173(8):1075-81. doi: 10.1007/s00431-014-2289-3

29. Nguyen HT, Hurwitz RS, Defoor WR, Minevich E, McAdam AJ, Mortensen JE, Novak-Weekley SM, Minnillo BJ, Elder JS. Trimethoprim in vitro antibacterial activity is not increased by adding sulfamethoxazole for pediatric Escherichia coli urinary tract infection. J Urol. 2010;184(1):305-10. doi: 10.1016/j. juro.2010.03.084

30. Soldo D, Katić M. Racionalno propisivanje antibiotika u obiteljskoj medicini - prevencija rezistencije. Hrvatsko Društvo Obiteljskih Doktora, 2012. Zagreb

31. Škerk V, Krhen I, Kalenić S, Francetić I, Cvitković-Kuzmić A, Derežić D, Jeren T, Kes P, Kraus O, Kuvačić I, Tambić Andrašević A, Tešović G, Vrčić H. Smjernice antimikrobnog liječenja i prevencije infekcija mokraćnog sustava. Hrvatsko Društvo za Nefrologiju, Dijalizu i Transplantaciju 1-17., Zagreb
32. Turudić D, Batinić D, Miše B, Habuš I, Spajić M, Krnjak G, Milošević D. Urolitijaza - potencijalna komplikacija terapije ceftriaksonom. Paediatr Croat. 2014;58:15-7. (in Croatian) doi: doi: http://dx.doi.org/10.13112/PC.2014.3

33. Milosevic D, Mise B, Habus I, Topalovic-Grkovic M, Batinic D, Golubic AT, Turudic D. Urine saturation and promoter/inhibitor parameters and ratios in renal stone disease caused by ceftriaxone. Cent Eur J Med. 2013;8(3):354-7. doi: 10.2478/ s11536-012-0091-z

34. Bitsori M, Maraki S. Kalmanti M, Galanakis E. Resistance against broad-spectrum beta-lactams among uropathogens in children. Pediatr Nephrol. 2009;24(12):2381-6. doi: 10.1007/ s00467-009-1255-1

35. Chan J, Hui, M, Griffiths S. Multiple antimicrobial resistance in Escherichia coli urinary tract infection in hospitalized children in Hong Kong: 2006-2011. Kenes Symposia, April 29, 2012. Hong Kong S.A.R.

36. Johns Hopkins Guide, Second Meeting of the Subcommittee of the Expert Committee on the Selection and Use of Essential Medicines, Geneva, 29 September to 3 October 2008: Gentamicin - Ototoxicity in children.

37. Jakovljević E, Ilić K, Jelesić Z, Konstantinidis G. A one year prospective study on the antibiotic resistance of $E$. coli strains isolated in urinary specimens of children hospitalized at the University Pediatric Medical Center in Novi Sad, Serbia. Infection. 2013;41(6):1111-9.

38. Senel S, Karacan C, Erkek N, Gol N. A single-center experience of antimicrobial resistance patterns in pediatric urinary tract infection. Med Princ Pract. 2010;19(5):359-63. doi: $10.1159 / 000316373$

\title{
RACIONALNO LIJEČENJE INFEKCIJA MOKRAĆNOG SUSTAVA KOD DJECE U HRVATSKOJ
}

\author{
D. Milošević, D. Batinić, V. Trkulja, A. Tambić Andrašević, B. Filipović Grčić, K. Vrljičak, B. Nogalo, D. Turudić i M. Spajić
}

Otpornost na antibiotike u liječenju infekcija mokraćnog sustava sve se više povećava. Optimalan izbor antibiotika postiže se objedinjavanjem kliničkog iskustva s poznavanjem otpornosti na uobičajene bakterijske uzročnike mokraćnih infekcija kako u Republici Hrvatskoj tako i u državama njenog okruženja. Liječenje mokraćnih infekcija u djece je naročito zahtjevno zbog njihove dobi i sklonosti prema sistemskoj reakciji i ožiljčenju bubrega. Ako je primijenjena, parenteralnu primjenu antibiotika potrebno je što prije zamijeniti oralnim antibiotikom. Također nije uputno zanemariti niti financijski aspekt liječenja kojega je cilj postizanje optimalnog učinka uz minimalnu cijenu liječenja. Pritom se nikako ne smije zanemariti osnovni medicinski postulat primum non nocere kao conditio sine qua non.

Ključne riječi: Dijete; Mokraćne infekcije - farmakoterapija; Antibakterijski lijekovi-terapijska primjena; Antibakterijski lijekovi-rezistencija 